\title{
A COMPARISON OF THE COMPOSITION AND STRUCTURE OF TWO OAK FORESTS IN MARSHALL AND POTTAWATOMIE COUNTIES
}

\author{
Bruce A. Smith \\ McLoud High School \\ McLoud, OK 74851
}

\begin{abstract}
Key words: Forest, composition, crosstimbers, science education, vegetation structure
\end{abstract}

\begin{abstract}
In October 2011, high school students from McLoud High School sampled an oak forest in Earlsboro, Pottawatomie County. In July, 2012, students in the Pre-collegiate Field Studies Camp at the University of Oklahoma Biological Station sampled the Marshall County forest at the Buncombe Creek camp ground, located approximately 100 miles south of the Earlsboro forest and 1 mile north of the University of Oklahoma Biological Station. One component of each botany course was to study the composition and structure of an oak forest. These 2 forests were chosen to compare because of their similarity in composition and physical distance apart. They found 10 hardwood species in the Marshall County forest and 9 in the Pottawatomie County forest, with 6 species common to both. Quercus stellata was most important in both forests and most frequent in the Pottawatomie forest where the total density was $0.141 / \mathrm{m}^{2}$. Quercus stellata and Ulmus alata were most frequent in the Marshall County forest where the total density was $0.107 / \mathrm{m}^{2}$.
\end{abstract}

\section{INTRODUCTION}

The best way to learn how to identify the trees, shrubs, woody vines, and herbaceous plants of a forest, is to make frequent visits and practice field identification. High school students from McLoud High School and the Pre-collegiate Field Studies Camp at the University of Oklahoma Biological Station (UOBS) did just that; they made frequent visits, but to different forests. The McLoud High School students sampled a local forest, as well as a forest near Earlsboro, Oklahoma. After spending time in the forests, students learned to recognize the different shades of green, shapes and colors of tree bark, growth habits, blade complexity, leaf phyllotaxy, leaf margins, leaf shapes, leaf textures, leaf odors, and even the taste of leaves of different species.
By walking through the woods, I have learned the taste and effects of prickly ashstrong and bitter; numbing. I have learned the texture of hackeberry leaves-scabrous and rough one way, smooth another. I have felt the barks of trees. All this I have learned by walking through the woods.

Cindy Do

McGuiness High School Oklahoma City, Oklahoma

In October, 2011, McLoud High School students studied an oak forest near Earlsboro in Central Pottawatomie County $\left(35.425^{\circ},-97.0875^{\circ}\right)$. In July, 2012, Precollegiate UOBS students studied an oak forest at the Buncombe Creek Camp Ground $\left(33.52^{\circ},-96.48^{\circ}\right), 100$ miles south and 20 miles east of the Earlsboro forest, near the biological station in Marshall County. The two forests provide an 
interesting comparison and contrast due to their similarity in composition and 100 mile north to south difference in location.

Students determined the composition of the forest by first learning to identify species within each of the quadrats. Students then collected data that can be used in long-term ecological studies. The structure of the forest was determined by calculating density, relative density, frequency, relative frequency, basal area, relative basal area, and importance values of those trees and shrubs in the forest. By measuring relative importance and frequencies of hardwood species, rather than calculating leaf area indices or other seasonal changes, their comparison of data taken in July in Marshall County to data taken in October in Pottawatomie County is still valid.

\section{METHODS}

Students set up eighteen $10 \times 10$ meter quadrats in each forest at a maximum distance from each other. This increased the likelihood of encountering a greater variety of habitats. In each quadrat, trees and shrubs were identified to species or genus, and then diameters of living woody stems 4 $\mathrm{cm}$ or greater at breast height $(\mathrm{DBH})$ were measured. The more traditional method for measuring DBH has been to include stems $7.62 \mathrm{~cm}$ (3 in.) or greater (Greller et al. 1979, Phillippi et al.1988, Rudnicky and McDonnell 1989, Stalter 1981). Including stems of $4 \mathrm{~cm}$ or greater will include more individual woody plants and yield a more complete data set than most traditional studies. A more recent study in New York (Glaeser 2006) measured DBH of woody plants that were $2 \mathrm{~cm}$ or greater. Measuring $\mathrm{DBH}$ at $4 \mathrm{~cm}$ or greater in this study may make direct comparisons with other studies using traditional measurements problematic, but a more accurate comparison of these 2 sets of forest data is possible. With the number of student data collectors in a field class and the use of computers which can handle greater sets of data, this can be a cost-effective way to improve data collection for long-term studies.

Students were taught to determine density, relative density, frequency, relative frequency, basal area, and relative basal area for individual species using a simple calculator. To save time and improve accuracy, data from the forests were entered in an Excel 2010 program for 18 quadrats from each forest. Importance values were calculated by adding the three relative values for each species

\section{RESULTS}

In the Marshall County forest, 10 species were identified in the $1800 \mathrm{~m}^{2}$ sampling area. In the Pottawatomie forest, 9 species were found in the $1800 \mathrm{~m}^{2}$ sampling area. The 2 forests had 6 species in common: Quercus stellata (post oak), $Q$. marilandica (black jack oak), Carya texana black hickory, Fraxinus americana (white ash), Ulmus alata (winged elm), and Juniperus virginiana (eastern redcedar).

$U$. alata had the highest density in the Marshall County forest. Q. stellata had the highest density in the Pottawatomie forest. Q. stellata and $U$. alata had the highest frequency in the Marshall County forest. $Q$. stellata had a frequency of 1.00 , the highest frequency in the Pottawatomie forest. $Q$. stellata had the highest basal area in both forests. The 2 trees with the highest importance values respectively in both forests were Q. stellata and U. alata. The total density for the Pottawatomie forest was 0.141 trees $/ \mathrm{m}^{2}$ and the Marshall County forest was 0.107 trees $/ \mathrm{m}^{2}$. The total basal area for the Pottawatomie County was 21.2 $\mathrm{cm}^{2} / \mathrm{m}^{2}$. The total basal area for the Marshall County forest was $23.3 \mathrm{~cm}^{2} / \mathrm{m}^{2}$. The 6 common species in both forests had a relative importance of 0.944 for the Marshall County forest and 0.954 for the Pottawatomie County. 


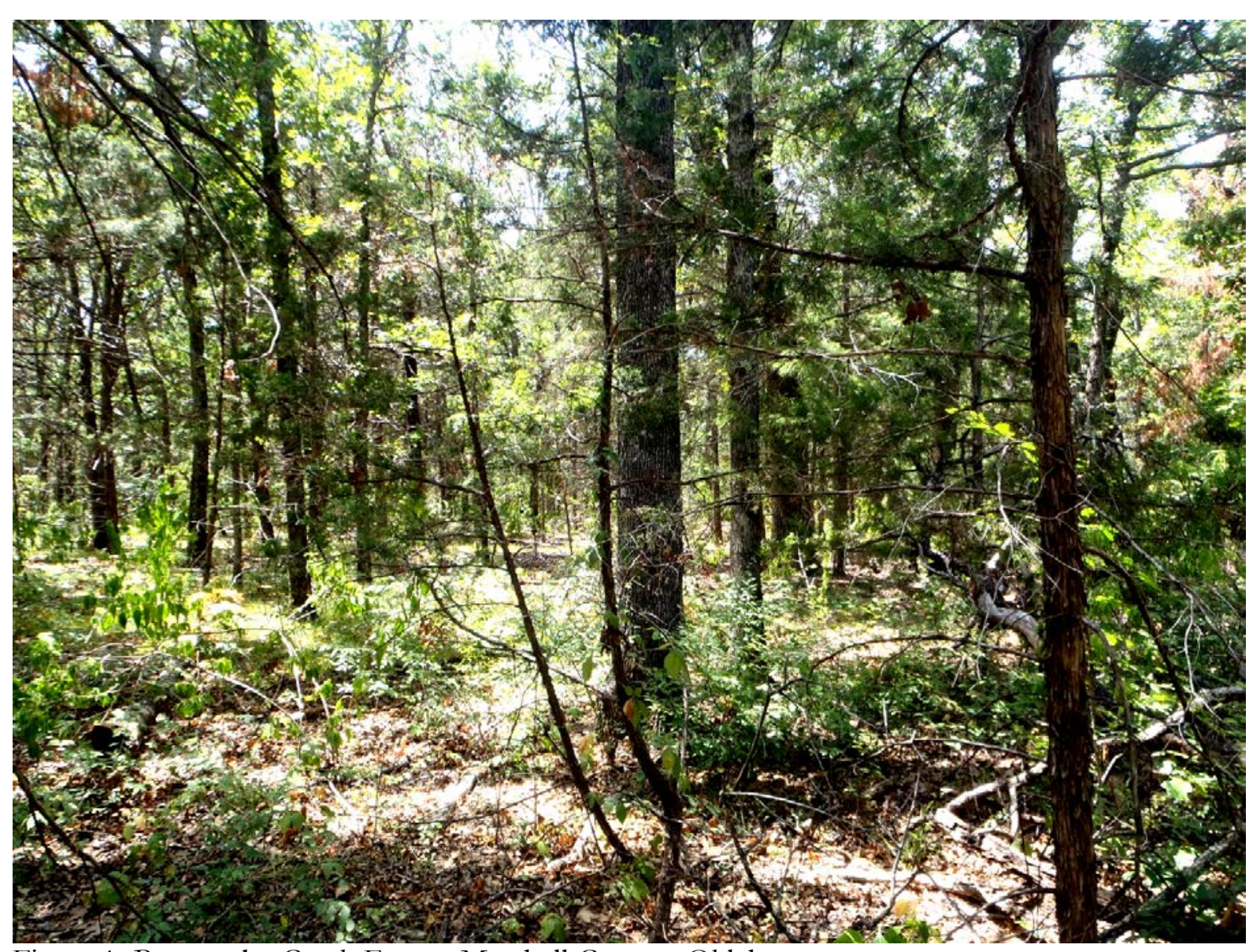

Figure 1 Buncombe Creek Forest, Marshall County, Oklahoma

Table 1 Density, frequency, basal area, and importance values for the Buncombe Creek Forest, Marshall County.

\begin{tabular}{|l|c|c|c|c|}
\hline \multicolumn{1}{|c|}{ Species } & $\begin{array}{c}\text { Density, } \\
\text { trees } / \mathrm{m}^{2}\end{array}$ & Frequency & $\begin{array}{c}\text { Basal area } \\
\mathrm{cm}^{2} / \mathrm{m}^{2}\end{array}$ & $\begin{array}{c}\text { Importance } \\
\text { value }\end{array}$ \\
\hline Quercus stellate & 0.0233 & 0.944 & 14.3 & 1.06 \\
\hline Ulmus alata & 0.0422 & 0.944 & 2.14 & 0.710 \\
\hline Jumiperus virginiana & 0.0161 & 0.722 & 1.31 & 0.378 \\
\hline Quercus marilandica & 0.0106 & 0.500 & 2.82 & 0.338 \\
\hline Carya texana & 0.00222 & 0.222 & 0.751 & 0.106 \\
\hline Fraxinus americana & 0.00778 & 0.444 & 1.42 & 0.239 \\
\hline Morus rubra & 0.00222 & 0.222 & 0.0850 & 0.0768 \\
\hline Vacinium spp. & 0.000556 & 0.0556 & 0.00698 & 0.0186 \\
\hline Prunus mexicana & 0.000556 & 0.0556 & 0.00698 & 0.0187 \\
\hline Quercus velutina & 0.00111 & 0.111 & 0.461 & 0.0565 \\
\hline
\end{tabular}




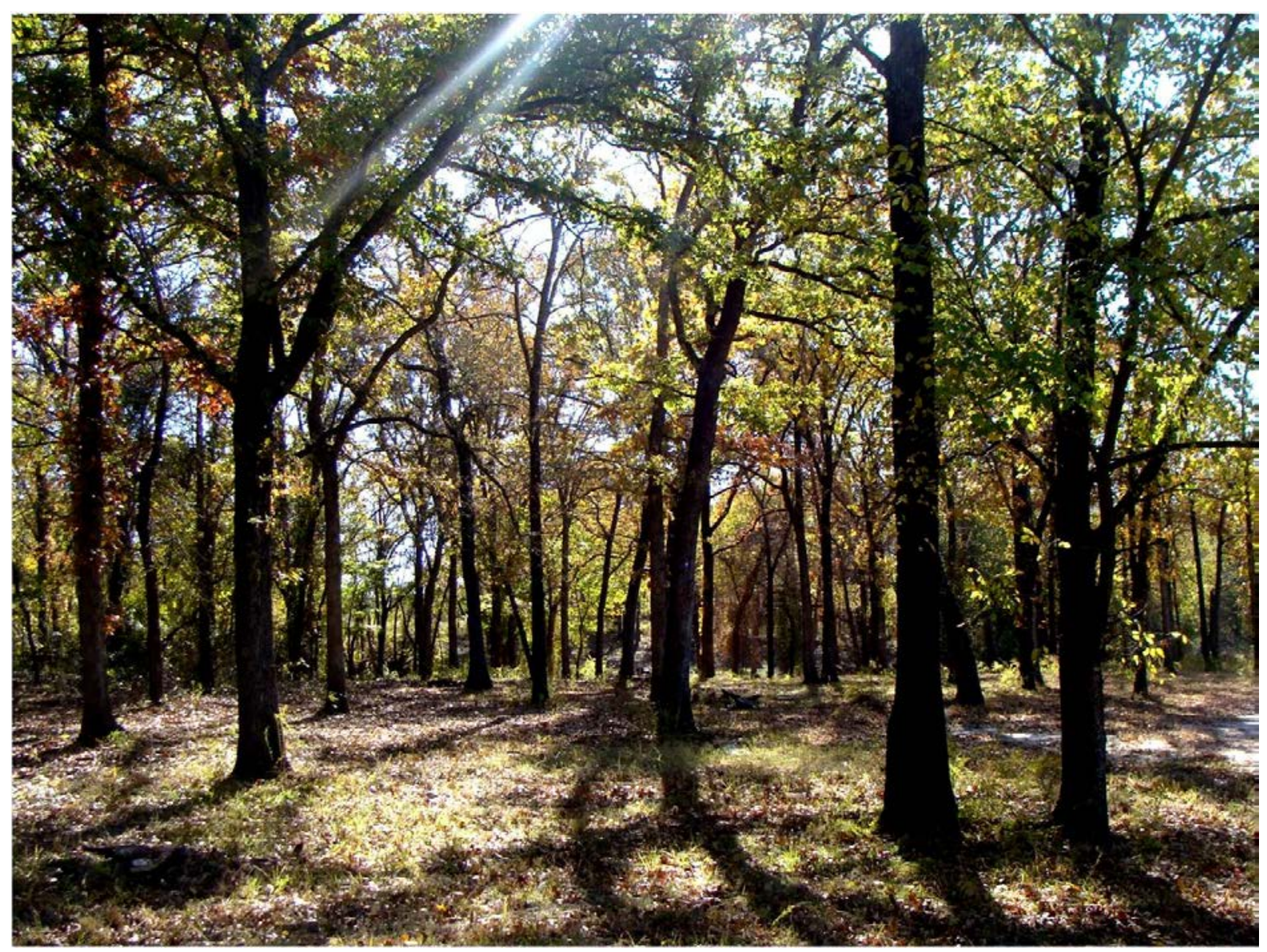

Figure 2 Earlsboro Forest, Central Pottawatomie County, Oklahoma

Table 2 Density, frequency, basal area, and importance values for the Earlsboro forest, Pottawatomie County.

\begin{tabular}{|l|c|c|c|c|}
\hline \multicolumn{1}{|c|}{ Species } & $\begin{array}{c}\text { Density, } \\
\text { trees } / \mathrm{m}^{2}\end{array}$ & Frequency & $\begin{array}{c}\text { Basal area } \\
\mathrm{cm}^{2} / \mathrm{m}^{2}\end{array}$ & $\begin{array}{c}\text { Importance } \\
\text { value }\end{array}$ \\
\hline Quercus stellata & 0.111 & 1.00 & 18.9 & 2.05 \\
\hline Ulmus alata & 0.0183 & 0.667 & 1.56 & 0.454 \\
\hline Jumiperus virginiana & 0.00278 & 0.222 & 0.0938 & 0.108 \\
\hline Quercus marilandica & 0.00278 & 0.222 & 0.233 & 0.114 \\
\hline Carya texana & 0.000556 & 0.0556 & 0.0109 & 0.0253 \\
\hline Fraxinus americana & 0.00222 & 0.222 & 0.241 & 0.110 \\
\hline Amelancbier spp. & 0.00111 & 0.111 & 0.0650 & 0.0526 \\
\hline Celtis spp. & 0.00167 & 0.111 & 0.0785 & 0.0572 \\
\hline Quercus shumardii & 0.000556 & 0.0556 & 0.0279 & 0.0261 \\
\hline
\end{tabular}




\section{DISCUSSION}

The relative importance values for the 6 common species show 2 very similar forests even though they are separated by at least 100 miles. At the same time, they are very different in terms of their composition of shrubs, understory trees, vines, and herbaceous plants of the forest floor. The Marshall County forest has a much denser forest floor, understory layer, and shrub layer than does the Pottawatomie County forest (Figures 1 and 2). Another major difference in the 2 forests is the dominance of post oak in the Pottawatomie forest, where Quercus stellata had the highest density, frequency, basal area, and importance value. The density of post oaks in the Pottawatomie forest is almost five times greater and the importance value is nearly two times greater than the post oaks in the Marshall County forest even though the post oak basal area did not differ much. Future studies might reveal the cause for these differences.

As a part of a field learning experience, students are able to collect large data sets over a long period of time, which might otherwise be prohibitively expensive to obtain. Furthermore, getting students into the field provides them with a depth of knowledge they could not possibly learn from reading a text or looking at dried specimens. While these studies provided an opportunity to begin a long-term ecological research project that involved students in field research, student identification of species in the field could be inaccurate to the point that it renders data useless. However, we found that allowing students time in the field to learn species identification (using more than a key and dried specimens) before beginning the field study, appeared to increase their accuracy. Students received immediate feedback regarding the accuracy of their species identification from instructors and teaching assistants, who were in the field with them.
The ecological value of this student research is that it creates baseline data for further research, to track changes in the 2 forests with possible links to changes in species due to global climate change. The greater value of this research is the invaluable experience for high school students, increasing their knowledge of nature and science aptitude by actually being in the natural environment (Louv 2011). They learn more than facts. They learn how to learn from the forest.

As I was walking through the forest; sun shining, elm leaves fluttering, birds flying, critters bustling, it occurred to me; mother nature teaches the purest kind of wisdom: you don't need to be in a classroom to learn. Knowledge is everywhere.

\section{Magen Clark and Caitlyn Carr McLoud High School McLoud, Oklahoma}

Beginning this long term study will also provide a beginning set of data to test hypotheses regarding how students learn in the field, versus how they learn in the lab or classroom. While I am confident that students have learned to identify trees during this project, future field studies should be accompanied by assessment of student identification skills comparing both field and laboratory experiences. This outdoor experience meets C3 PASS Standards 1 and 2 (Oklahoma PASS 2006) for general biology.

\section{ACKNOWLEDGMENTS}

I would like to give special thanks to the 2011-2012 McLoud High School Botany Class and students in the 2012 Pre-collegiate Field Studies Camp. I would also like to thank Alonna Price, Evan Smith, and Jimmie Manyanga for their assistance in the Buncombe Creek Forest. Thank you to Austin Carroll and Colby Brackett for 
providing the statistical program. Thank you, Debbie and Jay Mize, for allowing us to sample your wonderful forest in Earlsboro. Thank you, US Army Corps of Engineers at Buncombe Creek, for allowing us to study and collect samples in the forest for many years. Thank you, Crissy Smith and the Corps of Engineers, for help with the GPS coordinates. Thank you, Richard Butler, for looking over my rough draft. Thanks to the reviewers of this article. And finally thank you, Ron Tyrl. It was in the summer of 1990 that Dr. Tyrl shared with me how to study the composition and structure of forests using simple statistics. You cannot imagine how much mileage I got from that simple lesson.

\section{LITERATURE CITED}

Glaeser, C. W. 2006. The floristic composition and community structure of the Forest Park Woodland, Queens County, New York. Urban Habitats 4(1):102-126.

Greller, A. M. 1979. A vascular flora of the forested portion of Cunningham Park, Queens County. New York. Corrections and Additions I. Bulletin of the Torrey Botanical Club 106:45.

Louv, Richard. 2011. The Nature Principle. Chapel Hill (NC): Algonquin Books of Chapel Hill.

Phillippi, M. A., E. I. Collins, J. L. Bruner, and R. J. Tyrl. 1988. Succession changes in a Salix nigra (Salicaceae) forest in south-central Oklahoma, USA.

Transactions of the Illinois Academy of Science 81:61-70.

Oklahoma Priority Academic Student Skills, 2006 Oklahoma. [cited 2012 Nov]. Available from:

http://ok.gov/sde/sites/ok.gov.sde/file s/C3\%20PASS $\% 20$ sci.pdf

Rudnicky, J. L. and McDonnell, M. J. 1989. Forty-eight years of canopy change in a hardwood-hemlock forest in New York City. Bulletin of the Torrey Botanical Club 116:52-64.

Stalter, R. 1981. A thirty-nine year history of the arborescent vegetation of Alley Park, Queens County, New York. Bulletin of the Torrey Botanical Club 108:485-487. 